\title{
MEDICAL MALPRACTICE ON TRIAL: QUALITY OF CARE IS THE IMPORTANT STANDARD
}

\author{
Randall R. BovbjerG*
}

INTRODUCTION

One should judge today's tort-and-insurance system for medical malpractice by traditional tort standards: would a reasonable person, asked for informed consent, choose this particular system as a means of policing medical care and paying for medical injuries? The short answer is "probably not," but a full analysis must weigh the system's costs against its benefits, then compare the results against those of feasible alternatives. In this calculus, quality medical care is the most important element.

Significant costs of today's medical malpractice system include relatively objective fiscal elements like private liability insurance premiums (including self-insurance) that cover awards for economic loss and for pain and suffering, as well as public spending for courtrooms, judges, and juries. Highly subjective and intangible costs also need to be counted, such as the effects on medical practice and the availability of care, the impact of delayed compensation or rehabilitation on injured patients, time costs of plaintiffs and defendants, and damage to professional reputations and patient trust. Traditionally, benefits of the tort system are said to take two formscompensation and deterrence. ${ }^{1}$ Claimant-plaintiffs injured by the substandard behavior of a defendant-insured are to be "made whole" for the legally cognizable damages incurred. And, by virtue of having to pay in full for the consequences of their mistakes, medical providers are deterred from faulty conduct, so that quality of care is maintained. The heated debate over medical malpractice and other civil remedies, however, shows the influence of a third benefit for many people-an almost indefinable sense of accountability or retribution that comes from the operation of a fault-based system of compensation and deterrence. ${ }^{2}$

This cost and benefit calculus is easy to describe but difficult to implement. The quality of available evidence is poor. Moreover, both supporters and

\footnotetext{
Copyright $\odot 1986$ by Law and Contemporary Problems

* Senior Research Associate, Health Policy Center, The Urban Institute, Washington, D.C.

1. See, e.g., W. Seavey, P. Keeton \& R. Keeton, Cases and Materials on the Law of Torts 1 (1954).

2. Special Committee on the Tort Liability System, Am. Bar Ass'n, Towards a Jurisprudence of Injury (report to the Am. Bar Ass'n 1984) (lists many benefits not analytically separate from the three noted here, for example, availability of grievance mechanisms, risk spreading, and retribution).
} 
detractors of the status quo engage in strategic omissions and exaggerations in evaluating that evidence. They also assign different weights to the intangible elements. Finally, virtually all discussions, including most of this paper, treat all medical care and all types of malpractice in the aggregate rather than attempting to differentiate among different areas.

This article contends that the value of the tort and liability insurance system as a deterrent to substandard medical care is the most important factor to consider. The system inefficiently delivers compensation, and its intangible costs and benefits tend to offset one another. The liability deterrent probably does help improve the quality of certain medical care, although not nearly as effectively as one might like. Overall, other quality protections are probably more important than malpractice law to patients' well being. There is some danger that well-intentioned reforms that cut back across the board on plaintiffs' rights to compensation without providing effective replacements will reduce the number of valid claims along with invalid ones. They may thus weaken existing quality incentives without substituting effective replacements, whether through regulatory or market-oriented means.

Because today's system handles so few of the valid claims that could be brought, medical quality would probably be better served in the long run by increasing rather than reducing the number of liability claims. Such an improved system should simultaneously reduce the expense and agony involved in each case and strengthen other quality-control mechanisms that are better suited to address aspects of medical care poorly reached by malpractice law. These goals are more easily stated than achieved and would not make the system cheaper, just more valuable.

\section{II}

\section{Costs of the Malpractice System}

The malpractice system is expensive. The most obvious cost is that of liability coverage for providers. The A.M. Best Company reports premiums for conventional insurance totalling some $\$ 2,257,760,000$ in $1984 .{ }^{3}$ Amounts allocated for various alternatives, such as self-insurance, reinsurance only, or coverage by a "captive" insurer, are not tabulated, but are probably somewhat less. ${ }^{4}$ It is estimated that physicians bear nearly two-thirds of this "premium" burden, and hospitals bear most of the remainder. ${ }^{5}$ As a share of gross revenues, malpractice premiums are in the range of three to five percent for doctors, and under one percent for hospitals. They total about one to one

3. Best's Ins. Mgmt. Rep., General Liability and Medical Malpractice Insurance Marketing-1984, Sept. 2, 1985.

4. Posner, Trends in Medical Malpractice Insurance, 1970-1985, Law \& Contemp. Probs., Spring 1986 , at 37,44 .

5. This estimate is based on information supplied to the author personally by insurance company executives. 
and one-half percent of overall personal health care spending, although with wide variation by provider, specialty, and location. ${ }^{6}$

Through 1984, the premium percentages had changed little since the mid1970 's "crisis" in coverage, which itself significantly raised the earlier figure of about one-half of one percent. ${ }^{7}$ These percentages may have edged up again somewhat as a result of 1985 developments. In the aggregate, malpractice costs are (in a sense) borne by patients and their health insurers who pay for care. When liability premiums increase, however, providers may or may not be able to "pass through" the full increase, depending on health insurance payment rules and market resistance to price rises ${ }^{8}$ as well as on how smoothly the insurance market works in translating costs into premiums. ${ }^{9}$

Few of the additional costs often attributed to the malpractice system are well documented. Physicians lose time from practice to defend lawsuits and sometimes hire counsel independent of their liability insurers, but the dollars involved are small relative to insurance premiums. ${ }^{10}$ Similar time costs for plaintiffs appear not to have been estimated. Both plaintiffs and defendants also endure some emotional costs of disputation and delay, the value of which is unknown but which may be considerable in particular cases. ${ }^{11}$ The judicial

6. See Posner, supra note 4, at 49-51; Zuckerman, Koller \& Bovbjerg, Information on Malpractice: A Review of Empirical Research on Major Policy Issues, Law \& Contemp. Probs., Spring 1986, at 85, 92-93.

7. See Zuckerman, Koller \& Bovbjerg, supra note 6, at 93 . The lack of change in apparent premium burden is somewhat deceptive, since the pattern of coverage has changed. The increasingly common "claims-made" coverage spreads risk from the coverage year's incidents of malpractice into future years-and future premiums. This shift has held the growth of premiums below what it would have been under previously universal "occurrence" coverage. On the other hand, providers have surely raised the upper limits of their coverage-given rising awards-which increases premiums for what is considered adequate protection.

8. See Zuckerman, Koller \& Bovbjerg, supra note 6, at 106-07.

9. This article focuses on medical-legal issues at the expense of insurance ones. For many physicians, much of the malpractice cost problem is the abruptness with which premium rates can rise, often with essentially retroactive effect. Because malpractice claims are low-frequency events with high losses (or "severity") and trends must be extrapolated quite far into the future, initial expectations on which premiums are based can be subject to volatile shifts. Both the behavior of claimants and of legal rules and process seem unpredictable relative to insured events of many other lines of insurance. Premiums are also affected by cyclical trends in insurance and reinsurance markets generally. Regulators and other legal system actors may postpone or exacerbate shifts, making accommodation to price rises more difficult. See generally Posner, supra note 4; Roddis \& Stewart, The Insurance of Medical Losses, 1975 DukE L.J. 1281 . As this article goes to press, it appears that current pricing and availability problems for malpractice coverage are greatly influenced by far larger problems in liability and property-casualty insurance generally. See, e.g., Hilder, Small Firms Face Sharp Cost Hikes for Insurance-If They Can Get It, Wall St. J., Aug. 5, 1985, at 23, col. 4. Liability insurance problems generally have risen to the level of a Time cover story, Sorry, America, Your Insurance Has Been Cancelled, Time, Mar. 24, 1986, at 16, and White House attention, e.g., Liability Changes Proposed, Wash. Post, Mar. 18, 1986, at Al, col. 1.

10. Cf. Zuckerman, Koller \& Bovbjerg, supra note 6, at 107 (1983 average was about $\$ 250$ per physician per year).

11. On physicians' reactions to lawsuits, see Special Task Force on Prof. Liab. \& Ins., Am. Medical ass'n, Professional Liability in the '80s, Report 1, at 20 (originally published as a supplement to AM. MEd. News, Oct. 1984) [hereinafter cited as AMA TASK Force, REPORT 1,] (psychiatrist's survey of 14 physicians from Chicago area sued during 1977-1981). Some plaintiffs may delay appropriate rehabilitation for fear that otherwise they could not convince a future jury of the full extent of their injuries. Similarly, providers who see a chance to ameliorate iatrogenic injury may hesitate to act lest their action be seen as an admission of culpability. Conceptually, it is equally plausible that fear of future damages might encourage providers to promote early rehabilitation, 
system itself is hardly free, although it is not clear what share of its costs should be apportioned to malpractice.

Truly large cost estimates, however, arise only from calculations about socalled "defensive medicine," notably the extra tests and procedures undertaken not for medical purposes but for their potential defensive value in a lawsuit. The American Medical Association's official 1984 estimate of $\$ 15.1$ billion annually is frequently cited. ${ }^{12}$ An informal estimate of approximately $\$ 40$ billion has also been published. ${ }^{13}$ Despite their wide circulation, ${ }^{14}$ these huge estimates almost certainly exaggerate a very real problem. ${ }^{15}$ In addition to practicing such "positive" defensive medicine, providers may also be deterred from undertaking valuable but risky procedures, that is, they may practice "negative" defensive medicine. In the extreme case, practitioners may withdraw from certain medical fields altogether to avoid suit or high malpractice premiums. For instance, some obstetricians no longer deliver babies and some physicians have retired early. ${ }^{16}$ Withholding services may be a larger problem than adding unnecessary ones, but the withholding and its effect on patient access to needed care remains wholly unquantified. ${ }^{17}$ Finally, some observers count the erosion of the traditional and beneficial trust between patient and provider as a cost of an expanding malpractice system. ${ }^{18}$ This apparent erosion could just as easily cause more claims as result from them, however. Part of what has also been lost is not trust, but rather unquestioning deference to professional authority, which itself has its costs as well as its benefits.

Although many costs are unquantified or unquantifiable, they are clearly high, at least relative to costs for the preceding generation. The costs may be sharply increasing as well, given the current trends in liability premiums generally. A significant question is whether the changes in the insurance markets mainly represent a cyclical swing or rather a permanent ratcheting upward of prices similar to what seems to have occurred a decade ago. ${ }^{19}$

especially among potential plaintiffs who might be less likely to sue if attended to promptly. Apparently no empirical evidence on this question exists.

12. AMA TASK ForCe, RePORT 1, supra note 11, at 16

13. Brinkley, AMA Study Finds Big Rise for Claims in Malpractice, N.Y. Times, Jan. 17, 1985, at A1, col. 4 (AMA internal study estimates $\$ 40$ billion in defensive tests and treatments).

14. Fine \& Sunshine, Malpractice Reform Through Consumer Acceptance and Consumer Education: Are the New Concepts Marketable?, Law \& ConTemp. Probs., Spring 1986, at 213, 215.

15. See Zuckerman, Koller \& Bovbjerg, supra note 6, at 108-09; accord Mills, Infomation Please, $6 \mathrm{~J}$. LEGAL MED. 255, 256-58 (1985).

16. See, e.g., Malcolm, Fear of Malpractice Suits Leading Some Doctors to Quit Obstetrics, N.Y. Times, Feb. 12, 1985, at A1, col. 1; OBs, Surgeons Fight State Insurance Pinch, AM. MED. News, Feb. 14, 1986, at 1 , col. 3 (reporting that $70 \%$ of Mass. obstetricians plan to stop taking new patients). But see Knox, Why Mass. Doctors Are Saying No, Boston Globe, Feb. 9, 1986, at 1, col. 4 (only $1 \%$ of all doctors curtailed services in Massachusetts, most only temporarily).

17. Zuckerman, Koller \& Bovbjerg, supra note 6, at 109-10. When providers cease to perform some procedure, they clearly lose access to patients, but whether patients lose access to care depends upon what other providers do.

18. E.g., Cohn, The Price of Malpractice, Wash. Post, Mar. 12, 1986, (Health), at 12, col. 1, ("new lack of trust" worst effect of "malpractice crisis").

19. Cf. Posner, supra note 4, at 48-49 (on insurance cycles). 
Whatever the current costs may be, however, they should be compared with their benefits, not with the costs of last year or of the last generation of providers.

\section{III}

\section{Benefits of The Malpractice System}

\section{A. Accountability}

Perhaps the most fundamental, but also the most intangible, benefit of our fault-based liability system is the sense of fairness and accountability that it provides. This benefit goes beyond the value of compensating particular individuals and deterring particular substandard practices. For malpractice, as for much of tort law, most people like the idea that wrongdoers can in theory be called to account and made to pay for their transgressions. Quite apart from penalizing specific errors and compensating their victims, the existence of a malpractice remedy allows patients to command more attention from providers. ${ }^{20}$ Moreover, while almost any accident engenders sympathy for the innocent victim, "accidents" caused by a culpable party also engender a desire for personal and social retribution. The world seems a "righter" place where such wrongdoing is detected and social values of good conduct are overtly emphasized.

The American consciousness often naturally turns to tort law and litigation-with their clear-cut battles over right and wrong-to vindicate these philosophic and emotional desires for accountability and retribution. In this sense, tort actions-even without punitive damages-are a halfway house for affronts to justice that are not severe enough to warrant criminal prosecution. Where punitive damages are sought, tort law parallels criminal law even more closely.

Analysis can do little more than note that this intangible benefit exists, at least for some types of claims. Its influence is evident in reform debates about reducing the role of fault in liability and insurance systems generally. ${ }^{21}$ How highly valued it is cannot be directly assessed. It seems fair to conclude that individuals seldom consider the issue because they never "buy" justice directly, but only indirectly through social choices; and people may well underestimate its costs, given widespread liability insurance. In any event,

20. Havighurst, Reforming Malpractice Law Through Consumer Choice, Health AfF., Winter 1984, at 63,66

21. Both potential defendants and potential plaintiffs may reject departures from fault-based determinations of liability. Indeed, one of physicians' most heated complaints is that many of today's malpractice determinations already impose liability without real regard to fault, at least in cases of particularly sympathetic plaintiffs. They seem to feel that only much more negligent behavior should be deemed liable. Among the general public, the clearest example of this phenomenon comes from the debate on no-fault versus fault-based automobile liability systems. See, e.g., Finger Pointing Precedes Showdown on No-Fault, Wash. Post, Nov. 18, 1985, at C1, col. 5 (legislator's vote against no-fault explained: "constituents want to sue"); Herbert, What's Wrong with Finding Fault?, Wash. Post, Nov. 23, 1985, at A21, col. 3 (letter to the editor). It can be argued that the personal injury bar has fostered this demand for fault finding, but the reverse may also be true. 
these imponderable factors tend to confound dispassionate consideration of the effects of the malpractice system and of reform proposals. Compensation and deterrence are more readily discussed.

\section{B. Compensation}

As a method of compensating injured patients, malpractice law and insurance fail miserably. The litany of complaints about malpractice liability as a compensation system is well known. First, and most tellingly, very few injured patients ever bring a claim, much less receive any compensation, even after years of rapid growth in claims frequency. ${ }^{22}$ Malpractice recoveries may be important to meet medical bills and lost wages resulting from some medical injuries, presumably the more serious ones which may exhaust other sources of coverage, but recoveries are not, in the aggregate, a major source of compensation. Second, the "carrying charges" for determining and delivering that compensation are quite high, compared with other compensation systems. Malpractice claims return perhaps forty to fifty cents on the insurance dollar, similar to the return on auto liability coverage, but only half or less of the return on private disability or health coverage, and less yet than social "insurance" like Social Security or Medicare, for which administrative expenses claim only a few percentage points of program

22. This phenomenon has long been noted, e.g., Pocincki, Dogger \& Schwartz, The Incidence of Ialrogenic Injuries, in U.S. DeP'T OF Health, Educ., and Welfare Report of the Secretary's Commission on Medical Malpractice \& Appendix app. 50 (1973), but it is not well documented. A reasonable current estimate is that, at the very most, one in five medical mistakes in hospitals leads to a claim and, at most, one in ten receives any compensation. This very rough estimate is the only reasonable calculation that can be made. It rests on ten-year old data from a sample of 1974 hospital injuries in California and a virtual census of malpractice claims closed shortly thereafter, updated to today's experience by assuming a doubling of claims frequency and slight increase in likelihood of recovery (with no change in negligence) since then. Because California has high claims frequency, its experience overstates that of the nation at large. See Zuckerman, Koller \& Bovbjerg, supra note 6, at 94-95; see also P. Danzon, Medical Malpractice: Theory, Evidence, and Public Policy 20-25 (1985).

Virtually nothing is known about outpatient care, which is mainly performed in physicians' offices, although some $22 \%$ of paid claims originate in non-hospital incidents. See NAT'L Ass'N INs. Comm'rs, Malpractice Claims: Final Compilation (M. Sowka ed. 1980) (medical malpractice closed claims 1975-1978).

The problem of negligent damage that is never brought into the malpractice system might be larger or smaller outside the hospital setting. On the one hand, one might surmise that existing quality control and patient oversight is best in the highly organized institutional setting so that accidents there are reduced, and when they do occur they are dealt with more rapidly. On the other hand, the most serious diagnosis and care gravitates to hospitals, so that the likelihood of doing comparable harm outside them seems reduced-at least in terms of the significant economic injury needed to justify the high cost of bringing a malpractice action. Ample medical documentation exists, going back to the pioneering study a generation ago by Osler Peterson, of astonishingly lowquality outpatient care. Peterson, Andrews \& Spain, An Analytical Study of North Carolina General Practice 1953-1954 (pt. 2), 31 J. MED. Educ. 1 (1956) (60\% of physician office therapy below acceptable standards). But no examination is known to exist of how such low-quality outpatient practice relates to malpractice in the medical-legal sense. The issue is probably becoming more important as hospital cost-containment pressures and competition from lower priced delivery sites move more care outside of hospitals to ambulatory surgicenters, physicians' offices, nursing homes, and elsewhere. 
spending. ${ }^{23}$ Excessive lawyers' fees are often blamed for this low return, although it is infrequently noted that fees are similar on both sides.

Third, awards allegedly correspond poorly with the need for compensation as measured by economic loss, although evidence on this point seems quite mixed. ${ }^{24}$ Fourth, some critics have long opposed the tort standard of "full compensation" as excessive, at least as applied in medical cases, especially with regard to coverage of losses payable by collateral sources and for intangible "pain and suffering." 25 A similar argument has more recently emerged with regard to the nontaxability of tort payments for lost, otherwise taxable, income. Indeed, the tort goal of making a victim "whole" does go beyond what is paid by not-dissimilar coverage that people buy for themselves or by public programs, which universally leave some burden of loss on claimants. ${ }^{26}$ This extra generosity of tort law, not unique to malpractice, ${ }^{27}$ may reflect an extra increment for the wrongdoing of tortfeasors, an element not present in pure compensation schemes. It may also constitute a tacit acknowledgment of the need to finance high legal expenses, which are almost never necessary under first-party insurance, without unduly cutting into a claimant's "take home" compensation.

Fifth, and seldom-noted, malpractice awards may overcompensate because they fail to limit damages to the extra risk caused by the faulty behavior. ${ }^{28}$ Finally, compensation is often long delayed. Although forty-two percent of claims settle within a year of filing, fully five percent are not resolved after five

23. See Zuckerman, Koller \& Bovbjerg, supra note 6, at 100; P. DANzon, supra note 22, at 186.

24. Compare Nat'L Ass' $N$ of INS. Comm'rs, supra note 22 (differences in economic loss account for little of the variation in malpractice settlements), with P. DAnzon, supra note 22, at 39-42 (measures of compensable damages, plus legal doctrines, do significantly influence settlements). Available data make it difficult to assess this point; not only are claims files incomplete with regard to claimants' economic loss but payments also often fail to itemize damages; for example, they fail to isolate the amount of noneconomic "pain and suffering." P. DANzon, supra note 22, at 171-73.

25. E.g., O'Connell, Neo-No-fault Remedies for Medical Injuries: Coordinated Statutory and Contractual Alternatives, Law \& Contemp. Probs., Spring 1986, at 125, 125. 58.

26. Danzon argues this point of view most forcefully. See, e.g., P. Danzon, supra note 22, at $152-$

27. Although legal rules for assessing damage are essentially the same for all tort cases, it is sometimes argued that medical defendants are in practice made to pay more for similar injuries than are other defendants. The only apparent empirical evidence for such an assertion comes from a Rand Corporation study of Cook County litigation. M. Peterson, Compensation of Injuries: Civil. Jury Verdicts in Cook County 29-34 (The Rand Corp. Report No. R-3011-ICJ, 1984), Both malpractice defendants and corporate defendants in product liability cases were found to pay considerably more for similar injuries than less well insured defendants, like automobile owners. See the discussion in Zuckerman, Koller \& Bovbjerg, supra note 6, at 100.

28. Cf. Bovbjerg, The Medical Malpractice Standard of Care: HMOs and Customary Practice, 1975 DuKE L.J. 1375, 1403-06 (phenomenon in HMO context). Allocation of damages according to the degree of culpability may sometimes occur in the context of comparative negligence or of joint and several liability. Similarly, where the damage consists of negligently failing to diagnose or treat an underlying condition (a relatively uncommon ground for a claim), recovery (at least in theory) should be apportioned in light of what damage the condition would have caused even if well treated. When negligence causes a new problem, however, as in the typical case, the defense must pay for all damages to make the plaintiff "whole" as though there would otherwise have been $100 \%$ success. Neither the medical profession nor the law likes to recognize that good medicine often fails to achieve $100 \%$ success or that no patient awaiting treatment is "whole," given that even the best treated patient must run some risk. 
years. ${ }^{29}$ Moreover, interim payments for timely rehabilitation are not generally available under liability coverage; most such funding naturally comes from other sources in any case.

These often repeated complaints about compensation address the payments that are actually made-and generally conclude that they cost too much. The most damning indictment of malpractice as a compensation system, however, remains that so few people with a valid case for compensation actually bring a claim, and still fewer of these are paid. ${ }^{30}$

If compensation were the only function of malpractice law and insurance, society would have scrapped the system long ago. Indeed, our personal and social choices show that we rely hardly at all on malpractice remedies to cover ourselves against losses from medical accidents. Instead, almost all damages are met by other private or public mechanisms, such as health and life insurance, sick pay, disability coverage, and other third-party programs, not to mention patients' personal income or assets, and providers' charity. ${ }^{31}$ In the real world, what tort law calls "collateral" sources are the main sources of actual compensation. The malpractice system, however, is not a compensation system but is rather a liability system. The system should be judged mainly in terms of its intended deterrent effects, which play no part in the first-party insurance or social programs that work much better for compensation.

\section{Deterrence}

1. Problems in Assessing Deterrence. Does the threat of malpractice improve the quality of medical care by reducing the likelihood or extent of substandard care? Intuitively, the answer should be yes it does, to a certain degree. Unfortunately, the emotions roused by this question are matched only by the lack of evidence on it. This lack seems astonishing, given the central importance of deterrence as a justification for the various costs of an increasingly expensive malpractice system. Documentation is very poor even

29. P. Danzon, supra note 22, at 193. As Danzon notes, increasing the speed of resolution might be costly. Id. at 194. Critics of the tort system would also be disappointed if greater speed (and hence lower costs in time and uncertainty) led more claimants to hold out for trial or to file claims to begin with.

30. See P. Danzon, Why Are Malpractice Premiums So High-or So Low? 23 (The Rand Corp. Report No. R2623-HCFA, 1980) See also note 22 supra and accompanying text.

31. Like many obvious truisms about medical injuries, this one is hard to document. No broad studies seem to exist of injured patients to determine how their losses were met. Cf. Zuckerman, Koller \& Bovbjerg, supra note 6, at 99-100. Indeed, even malpractice insurance claims files often in the past failed to indicate what other sources had paid for damages, P. DANZoN, supra note 22, at 17173, although data must since have improved in jurisdictions where the extent of collateral sources can now influence malpractice awards. As a practical matter, it suffices to note that some $90 \%$ of the population has health coverage and presumably uses it to pay for medical accidents. In contrast, only a small fraction of people injured by medical mistakes receive malpractice compensation. See text accompanying note 22 supra. 
about whether the system has any deterrent effects much less about how great the deterrent is for various types of care or how it might be improved. ${ }^{32}$

Empirical data are almost wholly lacking and may be impossible to develop. "Quality" is an elusive concept and is very hard to define or specify, ${ }^{33}$ much less measure, and not just in medical care, as anyone can testify who has ever tried to write precise specifications for a product, service, or job. Assessing or measuring the quality of medical care is especially difficult given how often medicine is as much an art as a science and given the complexities of the human organism whose functioning medicine tries to improve is so complex. Moreover, quality goes beyond technical medical matters to include aspects of personal service such as providing information and solace, and making patients "feel better" in intangible ways.

Merely reaching professional consensus on the narrow issue of whether a new procedure works as intended can take years and hundreds of published clinical reports or massive randomized experiments. ${ }^{34}$ Broader quality assessments are almost never attempted. There is general agreement that the most important quality measures are treatment outcomes, such as patient survival versus death and return to normal functioning versus disability. Actually implementing such concepts has proven an elusive goal. Patients seeking counsel on where and how best to treat a condition must ultimately rely on more or less informed expert judgment-as do courts considering whether malpractice has occurred. So, too, society must for the moment be content with reasoned opinion in attempting to assess the deterrent value of liability rules and process.

A major problem, of course, is that the professional experts on deterrence are so divided on its effect-too often along predictable lines of economic self-interest. Further, the experts' assessments seem to rely more on anecdotes and hunches than on well compiled "clinical" experience, much less on dispassionate weighing of broader evidence. Finally, conflicting opinions about quality and deterrence can all be "right" depending on the experts' perspective. Plaintiffs' lawyers know from experience that egregious mistakes "often" occur; the self-selected results appear in their offices. Doctors, to the contrary, know to their dismay that bad outcomes "often" occur for no obvious reason at all, much less one related to a particular failing of medical skill or performance.

32. Cf. Zuckerman, Koller \& Bovbjerg, supra note 6 , at 87 (little evidence on quality and malpractice). One major compilation of health services research did not even include the malpractice system as a category related to health outcome. L. Freeburg, J. Lave, L. Lave \& S. Leinhardt, l Health Status, Medical Care Utilization and Outcome: An Annotated Bibliography of Empirical StUdies (NCHSR Research Report Series No. 78-184, 1979). Nor did a review of the literature on quality of medical care. See infra note 33.

33. See, e.g., Donabedian, Needed Research in The Assessment and Monitoring of the Quality of Medical Care (NCHSR Research Report Series No. 78-145, 1978); see also Anderson \& Shields, Quality Measurement and Control in Physician Decision Making, 17 Health Services Research, Summer 1982, at 125 .

34. See generally Donabedian, supra note 33 , and sources cited therein. 
2. Specific Contentions. Lacking systematic evidence, legislators and others must rely on intuitive judgment in deciding where between the extreme positions the truth probably lies. There is no lack of particular arguments about deterrence or the lack of it. Any would-be assessor is left to consider the contentions one at a time. To begin with the opponents:

a. Liability is simply irrelevant to good medical practice. One of the more common assertions is also the crudest. The contention is that because only professional and technical concern for the patient matters, potential liability is irrelevant to the quality of care. In light of the simultaneous assertion that providers respond to potential liability with enormous amounts of nearly worthless "defensive medicine," it seems highly implausible that providers do not at least try to improve medical outcomes as well. The best defense against a claim, after all, is that no damage has occurred.

\section{b. Malpractice claims strike haphazardly, like lightning bolts. The second} contention is that liability experience cannot serve as a guide for good medical practice, because the careful and careless are equally vulnerable. The lightning analogy runs through much malpractice commentary, ${ }^{35}$ despite its obvious weaknesses as a metaphor. ${ }^{36}$ In fact, claims do not seem to be as evenly distributed across practitioners as one would expect if claims were random events. Certain physicians, even within recognized specialty rating categories, for example, do seem to have more than their "share." 37 So, too, do certain insurers. ${ }^{38}$ Such findings are hardly conclusive, however, especially

35. See, e.g. Havighurst, supra note 20, at 67; Schwartz \& Komesar, Doctors, Damages and Deterrence, 298 New ENG, J. MED. 1282, 1282 (1978) (both studies list common criticisms).

36. Lightning damage, of course, only seems random, mainly because it is very rare in any one observer's personal experience, much as malpractice claims at least used to be. In fact, of course, lightning predictably strikes elevated objects and good conductors of electricity. Risk factors are thus in fact understood, as is prevention-either put up a lightning rod or lie low until the storm passes. An understanding of the causes and prevention of malpractice is far less well developed, in part because of the strongly held professional belief in the randomness of occurrences. Given providers' reactions to liability, a better metaphor might cast malpractice claims as the sword of Damocles - an act of man, not nature. Lawyers and patients have arbitrarily hung a malpractice sword above the medical professional's head as a reminder of medical vulnerability. The sword hangs by a thread and could drop at any time without regard to professional conduct. This metaphor is offered not as an accurate picture of malpractice rules and process, but rather of professional attitudes toward them.

37. See, e.g., Rolph, Some Statistical Evidence on Merit Rating in Medical Malpractice Insurance, $48 \mathrm{~J}$. RIsk \& INS. 247 (1981) (of 8,000 Los Angeles physicians studied over four years, $0.6 \%$ accounted for $10 \%$ of all claims and $30 \%$ of all payments).

38. According to data reported by the AMA, overall claims frequency for physician mutual insurers is almost double that of some other insurers. AMA TASK FORCE, REPORT 1, supra note 11, at 10 (1983 physician-owned insurers had almost one claim for every four covered physicians, whereas commercial insurers had only about one claim for every ten insureds). However, such aggregated information is unreliable in that it fails to adjust for different reporting practices or for the proportion of physicians covered in different known risk categories; general practitioners have far fewer claims than obstetricians or neurosurgeons. It is also difficult to document whether frequent defendants are bad practitioners or are good ones willing to treat the worst cases. But there is increasing acceptance of the idea that frequent defendants should at least be investigated further in the context of hospital privileges or state licensure. See Special Task Force on Prof. Liab. \& Ins., 
given the low probability per provider of having a claim in any one insured period.

It is clearly true that other factors than substandard care influence claims frequency, among them legal doctrines and urbanization; 39 a favorite hypothesis of medical providers is that nonmedical factors are the main cause-over-litigious patients and too many lawyers. ${ }^{40}$ There can be no direct test of the influence of substandard care on malpractice claims, or vice versa, because there is no clear-cut, agreed-upon, independent definition to use for analysis, much less statistics on amounts and locations of low quality. But one relevant analysis found that one available medical measure-extent of surgery per capita-was a better predictor of a state's claims experience than availability of lawyers. ${ }^{41}$ Even medical professionals sometimes acknowledge that " $[t]$ he reason for malpractice claims is malpractice." 42

c. The legal process itself is faulty. The expectations of claims adjusters, who in fact settle most claims, are guided by the likelihood that a certain malpractice claim will result in an adverse trial verdict. If courts and juries do not accurately assess whether substandard care caused the damage being reimbursed, liability obviously cannot correctly deter bad practice. The argument that trials and claims settlement do not rationally relate to bad care takes several forms:

(1) Malpractice claims resolution is a "lottery." Like the lightning metaphor for the haphazard bringing of claims, this oft-repeated assertion ${ }^{43}$ implies that the malpractice system is also random in how it settles claims. The metaphor is a powerful one, especially as applied to certain cases whose outcomes are unpredictable, notably large lawsuits that go all the way to a jury precisely because liability or damages are uncertain and hotly contested. But it is unwise to focus on the very few cases that are not settled before a jury verdict (and it is well to recall that defendants win most such cases). ${ }^{44}$ The most

Am. Medical Ass'n, Professional Liability in the '80s, Report 3, at 16 (originally published as a supplement to AM. MEd. News, Mar. 1985) [hereinafter cited as AMA TAsk Force, Report 3 ].

39. See Danzon, The Frequency and Severity of Medical Malpractice Claims, $27 \mathrm{~J}$. LAw \& ECON. 115 (1984).

40. Some physicians are even willing to pay for information about potentially litigious patients. See, e.g., Doctors and Lawyers Square Off on Legal Records, N.Y. Times, Dec. 26, 1985, at B17, col. 1 (entrepreneur claims "overwhelming response" to offer of data on patients' records in civil litigation); see also Malpractice Foes Enter Computer Age, MEd. World News, Dec. 9, 1985, at 22.

41. Medical Foes Enter Computer Age, supra note 40. Evidence is mixed about the influence of the availability of lawyers on claims and hence on premiums. See Zuckerman, Koller \& Bovbjerg, supra note 6 , at 96 .

42. AMA TASK ForCe, REPORT 1, supra note 11, at 23 (quoting James Todd, M.D., AMA's Senior Deputy Executive Vice President).

43. E.g., O'Connell, supra note 25 , at 127.

44. Tabulations of plaintiff' success vary. In 1975-1978, fewer than $10 \%$ of closed claims had gone to actual trials; of those going to jury verdict, plaintiffs won only about one-quarter. See $\mathbf{P}$. DANzon, supra note 22 , at 31 . 
thorough analysis of the entire claims settlement process concludes that it is indeed rational in that results are consistent with a logical predictive model. ${ }^{45}$

(2) Non-meritorious or frivolous suits clog the system, yet must be settled because of their "nuisance" value and therefore confound deterrent signals. During the last "crisis," this complaint was frequently voiced. Physicians were encouraged to bring countersuits for abuse of legal process, and "weeding out" such "frivolous suits" was a major goal of pre-trial screening panels. ${ }^{46}$ Today, this argument is seldom heard, in part because screening does not seem to eliminate the vast majority of claims, ${ }^{47}$ but perhaps even more importantly because providers themselves are much more involved in insurance generally and in claims settlement, through physician-owned mutuals and other arrangements. ${ }^{48}$

Outsiders rarely investigate actual malpractice settlements to assess them independently for merit; any such review can of course be criticized as "second-guessing," that is, for making a judgment without having all the facts that were available to claims adjusters and juries, nor their direct experiences with the evidence. ${ }^{49}$ There is some indication, however, that the bulk of settlements are reasonable. ${ }^{50}$

(3) Claims and recoveries keep climbing, even though medical care has never been better, so legal processes must be faulty and without reasonable deterrent effect. The premises of this contention seem true, but the conclusion does not follow. Claims have undeniably increased, and the ability of medical care to improve health has clearly improved enormously in the past two generations. But the

45. See P. Danzon, supra note 22 , at $30-53$, for a strong argument that claims settlement is rational, and that "despite its apparent perversities, the tort system in practice is far from random." Id. at 49. Danzon bases her argument, however, on an aggregate analysis of how well actual settlements relate to expected verdicts predicted by her conceptual model.

46. P. Carlin, Medical Malpractice Pre-Trial Screening Panels: A Review of the Evidence (George Washington Univ. Intergovernmental Health Policy Project 1980).

47. See P. DANzon, supra note 22, at 198-202, for a theoretical and empirical review of evidence on screening panels, concluding that they may slightly increase litigation while slightly reducing likelihood of a plaintiff award. But see Doctors and Lawyers Square Off on Legal Records, supra note 40 (physician asserts, "We know that 25 percent of medical malpractice suits are without merit.")

48. See generally Posner, supra note 4; Special Task Force on Prof. Liab. \& Ins., Am. Medical Ass'n, Professional Liability in The '80s, RePort 2, at 7-8 (originally published as a supplement to AM. MEd. News, Nov. 1984) (roundtable discussion by insurance executives) [hereinafter cited as AMA TASK FORCE, REPORT 2 ].

49. According to Dr. Todd of the AMA, 95\% of the dollars paid by physician mutual insurers are completely defensible by peer review standards. InTERnal MeD. NEws, Dec. 1-14, 1984. He and the AMA, of course, nonetheless feel that current legal rules are unfair to defendants and should be altered, specifically with regard to damages. See AMA TASK ForGE, REPORT 3, supra note 38, at 11-14.

50. One independent review covered 220 obstetrics claims closed by the industry's largest insurer during the period 1980 to 1982 in which either payment was made or $\$ 1000$ or more was spent on legal defense. Julian, Brooker, Butler, Joseph, Ogburn, Williams, Anderson, Shepard, Preisler \& Capell, Investigation of Obstetric Malpractice Closed Claims: Profile of Event, 2 AM. J. Perinatolocy 320 (1985) [hereinafter cited as Julian]. It did not specifically judge meritoriousness case by case but rather assessed the management of medically recognized risk factors in pregnancy and delivery $\longrightarrow$ of which there were 1001 risks in 220 cases. Id. at 321 . In the reviewers' medical opinion, only $54 \%$ of these were correctly recognized and documented by the providers involved, with two-thirds of these correctly managed (32\% of total); $66 \%$ of identifiable risks were involved in outcomes that led to claims. Id. Claims did arise, however, even in the $32 \%$ of correctly managed cases, although the authors do not report how many did so. Id. at 323 . 
standard of care (set by customary practice and proven by expert testimony) has risen along with medical capabilities. There is no indication that providers are relatively more (or less) careful today than formerly, compared to prevailing medical standards and hence reasonable social and patient expectations. ${ }^{51}$

(4) The legal process often bases awards not on faulty conduct but on need for compensation. A similar complaint is that patient-claimants and juries alike expect perfection and want compensation awarded whenever it is not achieved. ${ }^{52}$ This may be true in particular cases with sympathetic plaintiffs and unsympathetic defendants, especially with regard to the amounts awarded as opposed to the basic determination of liability. ${ }^{53}$ But it seems false in general. Most claims receive no payment, ${ }^{54}$ and far more medical injuries occur than ever appear as claims, much less as recoveries. ${ }^{55}$

d. Providers' liability insurance effectively eliminates whatever positive quality incentives liability might theoretically create. For malpractice, as for tort generally, liability coverage to pay awards removes defendants' direct financial incentive to avoid liability. Insurance has been severely criticized on this ground, ${ }^{56}$ more by academic commentators than by providers. Liability coverage, however, is not theoretically incompatible with maintaining deterrence, given the possibilities for experience rating and other mechanisms. ${ }^{57}$ One can also note that some tangible costs to defendants and many intangible ones are not insured. 58

51. See generally Brook, Brutoco \& Williams, The Relationship Between Medical Malpractice and Quality of Care, 1975 DukE L.J. $1179,1209$.

52. See, e.g., Malcolm, supra note 16 , at $\mathrm{D} 23$, col. 5 (obstetrician says parents' attitude is "[w]e're going to have fewer babies so we want a perfect baby"). Note, however, that if one obstetrician in six faced a claim in $1983, i d$, then this implies at most some 5,000 cases. Infant mortality in 1983 was about 40,000. U.S. Dep't of Commerce, Statistical Abstract of the United States 1986, at 56, table 81 (1985). Birth defects were far more numerous.

53. Quite apart from jury sympathies, the law does intentionally sometimes assign a larger share of damages to a defendant than was actually caused by his faulty conduct, notably through the doctrine of joint and several liability. E.g., Li v. Yellow Cab Co., 13 Cal. 3d 804, 532 P.2d 1226,119 Cal. Rptr. 858 (1975). Here, the goal of setting appropriate deterrent amounts that relate specifically to one defendant's own failures are quite explicitly subordinated to the compensation goal of making the injured party whole. The problem seems less severe for medical defendants, almost all of whom are insured, have considerable assets, or both, than for motorists and many other types of potential defendants who are more likely to be judgment-proof, and hence are able to shift larger amounts of an award to a less responsible party. For a description of problems outside the malpractice area, see American Motorcycle Ass'n v. Superior Court, 20 Cal. 3d 578, 578 P.2d 899, 146 Cal. Rptr. 182 (1978) (Clark, J., dissenting). See also discussion in note 28 supra; Sorry, America, Your Insurance Has Been Cancelled, supra note 9, at 23-24.

54. The National Association of Insurance Commissioners' survey of virtually all closed claims from 1975 to 1978 found that about half were closed without payment. Nat'L Ass'n Ins. Comm'rs, supra note 22, at 20. According to the AMA, about three-quarters of all claims that were closed during the period 1980 to 1983 by physician-owned insurers linked to medical societies were closed with no payment. AMA TASk FORCE, RePORT 2, supra note 48, at 6.

55. See supra note 22 and accompanying text.

56. E.g., Schwartz \& Komesar, supra note 35, at 1287-88.

57. See Shavell, On Liability and Insurance, 13 Bell J. Econ. 120 (1980).

58. See supra notes $10-11$ and accompanying text. 
In practice, various forms of experience rating and risk retention (including self-insurance) apply mainly to hospitals and other institutional providers, not to physicians, who pay the largest share of premiums. ${ }^{59}$ It is very curious that physicians and their insurers have not moved to rely partly on experience rating, if only through retrospective adjustment of dividends, which does not seem to pose unduly difficult conceptual or technical difficulties. ${ }^{60}$ It is plausible that physicians-who now write half their own coverage through mutual insurance ${ }^{61}$-resist experience rating because of the strongly held belief that claims are random. Resisting insurance reforms that might help some low rated providers also helps to maintain professional pressure for weakening tort rules, which could benefit all providers.

On the other side of the ledger, the documented evidence that malpractice claims do relate to substandard care is relatively weak, in large part for lack of careful scrutiny. Again proceeding argument by argument:

e. Medical care often fails to meet accepted professional standards. Defenders of the right to sue often emphasize that the basic malpractice problem is low medical quality, not legal rules or processes. ${ }^{62}$ It is possible to cite a considerable body of medical literature about quality failings in medical, not medical-legal terms. ${ }^{63}$ The one significant study to apply medical-legal malpractice standards to care found that nearly one percent of hospital admissions resulted in temporary or permanent disability or death as a result of faulty care. ${ }^{64}$ One percent is a large number, given almost forty million hospital stays a year. ${ }^{65}$ That quality deficiencies do exist, however, shows the need for more effective control mechanisms. It does not show that malpractice liability is, in fact, effective; this line of reasoning assumes the conclusion.

f. Other. In addition, some plaintiffs' lawyers report that cases they see from low-claim areas, often rural ones, show much worse practice than highclaim, big-city cases. ${ }^{66}$ Beyond these specifics, defenders of deterrence also reassert the general expectation that fiscal incentives act to promote caution and note that an injured patient has no other recourse.

59. See generally Posner, supra note 4.

60. See Roddis \& Stewart, supra note 9 , at 1302-03; Rolph, supra note 37. Danzon argues that it is economically efficient for physicians not to take deductibles in order to encourage vigorous defense of all claims by insurers. P. Danzon, supra note 22, at 114-36.

61. See Posner, supra note 4; AMA TASK FORCE, RePorT 1, supra note 11.

62. E.g., T. Goddard, The American Medical Association is Wrong-There is No Medical Malpractice Insurance Crisis (unpublished paper for the Public Affairs Department, Association of Trial Lawyers of America [1985]).

63. See, e.g., Brook, Brutoco \& Williams, supra note 51, at 1200-02.

64. See P. Danzon, supra note 22, at 20-25. An earlier pilot study using the same study method made an even higher estimate. See Pocincki, Dogger \& Schwartz, supra note 22, at 50.

65. U.S. Dep't of Commerce, Statistical AbStract of the United States 1986, at 110 , tables 175-76 (1985) (38.8 million hospital discharges in 1983).

66. This is based on the author's personal communication from plaintiffs' attorneys. They seldom describe quality improvements brought about by more litigation, other than improved record keeping. 
3. Deterrence in Perspective. One cannot reach a firm conclusion with great confidence about the law's deterrent influence on medical care. Economic theory and common sense agree that making responsible actors pay for faulty outcomes should help deter substandard practice. The burden of proof should lie with the nay-sayers, and they lack a convincing case. Evidence is sketchy and the contending positions are more argumentative than compelling.

There are better reasons to believe that considerable valuable deterrence exists than that large amounts of nearly worthless "defensive medicine" exist. Perhaps the most tangible indication of good defensive medicine has been the emergence of "risk management" programs in hospitals. ${ }^{67}$ In any case, to believe that providers care only about legal defense and not about helping patients by curbing errors seems a slur on medical ethics and professionalism. Nonetheless, there is room for very great improvement in deterrence.

\section{IV}

\section{Costs and Benefits Revisited}

\section{A. Compensation and Deterrence in the Balance}

Deterrence of substandard medical care is the most important benefit of the malpractice system. Compensation works badly, partly because of overcompensation but mainly because of undercompensation, and the accountability or vindication that tort law provides is quite an intangible benefit. ${ }^{68}$

The assessment of the malpractice system's benefits versus its costs depends on whether one thinks valuable deterrence outweighs poor compensation. ${ }^{69}$ The system's intangible costs and benefits can be seen as offsetting, and the most tangible net costs (excess of paid premiums over

67. Such programs have multiplied since the last "crisis" drew attention to malpractice recoveries as a growing problem and to hospitals as the prime site for injuries that lead to claims. Risk management remains in its infancy and most often seems to address "risk" in an insurance sense-after-the-fact damage control and attempts to limit legal liability for adverse incidents once reported or discovered. However, the field is definitely progressing; risk management has become a recognized occupation and many programs are now trying to address root causes as well as symptoms. Compare, for example, Federation of AM. Hosps., Risk Management Manual (1977) with any recent issue of the bi-monthly publication of the Risk Management Foundation of the Harvard Medical Institutions, Risk Management Forum, to see the increase in sophistication.

68. Accord P. Danzon, supra note 22, at 225-26. Without allowing for any independent value of accountability separate from deterrence, this leading economic analyst calculates that if the deterrent effect of malpractice reduces the extent of negligent harm by $20 \%$, it is worth its costs. She implicitly concludes that the deterrent effect is at least this large when she recommends retaining a fault-based litigation system, with modifications. The estimate is necessarily rough, lacking data on the incidence of negligence outside of hospitals and on the full costs of hospital liability coverage, including selfinsurance.

69. Indeed, those who attack the current system typically emphasize its failings in compensation. E.g., O'Connell, supra note 25 . They may mention deterrence but typically give it little attention. E.g., Fine \& Sunshine, supra note 14. In contrast, defenders often emphasize deterrence or at least the potential for it. E.g., P. Danzon, supra note 22, at 12-17, 225-27. 
delivered compensation) can be seen as the price society must pay for an important part of quality control for medical care. To this writer, approximately one percent of health care spending as of 1984 does not seem too much to pay for quality control, if it is effective. Nor do the net insurance costs of covering malpractice seem high relative to the extent of negligent harm they attempt to alleviate.

There is room for considerable disagreement on whether the benefits of the tort system exceed its costs. Reforms should seek to improve the balance, however, and not to make matters worse. The argument here is that policymakers contemplating changes should keep their eyes firmly on the bottom line, which is deterrence. This is true both for legislators who enact public reforms and for any health care consumers who agree to private reforms.

Unfortunately for deterrence, most reform proposals-iwhether for public or private action-seem primarily designed to cut back on the perceived overcompensation of some claimants. This effort seems desirable on cost grounds if it is well targeted rather than arbitrary, a topic that is beyond this discussion. Across-the-board cuts in compensation do not seem likely to improve compensation generally. It is notable, for example, that most proposals do little or nothing to correct current undercompensation problems. ${ }^{70}$ Given the high "carrying costs". of delivering compensation through tort law and liability insurance, the malpractice system seems almost hopelessly imperfectible as a compensation mechanism.

What do reforms accomplish for the true value (or at least potential value) of tort recoveries, namely deterrence? They accomplish very little. There is some effort to reduce invalid claims, for example, by having lawyers certify the merit of filings. But no one seems concerned about valid claims that are never filed. Most reforms simply attempt to cut back the cost of awards. Reforms that merely cut compensation to successful claimants and otherwise reduce the number of claims (for example, by limiting plaintiffs' lawyers' fees) may well actually reduce deterrence by lessening the likelihood of discovery of and recovery for substandard care. ${ }^{71}$ This effect is particularly unfortunate,

70. Havighurst, for one, recognizes the unfairness of today's system to nonclaimants and hopes that private agreements will at least allow the nonlitigous to negotiate for lower health care fees or insurance premiums. See supra note 20, at 68-70. Nonclaimants who are ignorant of their existing legal remedies pose a different problem, however. Under the Moore "no-fault" proposal, providers will be encouraged to make prompt offers of economic compensation so as to prevent claimants from suing for full damages, including noneconomic ones. See Moore \& Hoff, H.R. 3084: A More Rational Compensation System for Medical Malpractice, LAw \& ConTemp. Probs., Spring 1986, at 117. Whether providers will offer to pay many people not now compensated rather than concentrating on obvious tort claimants is an open question.

71. Danzon, for example, explains how some reforms affect claims frequency directly (such as reductions in the statute of limitations), whereas others, that directly cut only awards or claims severity (for example, collateral source rule changes), in fact, also indirectly reduce frequency by reducing incentives to bring claims. See, e.g., Danzon, The Frequency and Severity of Medical Malpractice Claims: New Evidence, Law \& Contemp. Probs., Spring 1986, at 57, 78-79. She nonetheless asserts, however, that reducing overcompensation can simultaneously improve compensation and deterrence. P. Danzon, supra note 22, at 226. 
coming as it does at a time when medical providers may be tempted to cut corners because of the financial pressure on them from health insurers to deliver care less expensively. ${ }^{72}$ Improving on the current system's deterrent effect seems an important goal, both within and possibly also outside conventional tort processes.

\section{B. Improving Malpractice Law, Process, and Incentives}

Three major types of changes hold promise for improving the malpractice system, especially for deterrence and quality promotion: (1) Improve confidence in the system's accuracy and fairness; (2) Review more cases, not fewer, through the improved system; (3) Improve the "feedback" mechanisms that motivate and educate providers. These goals will be difficult to achieve.

1. Improve Confidence in the Deterrent System. Deterrence depends in large part on the accuracy and fairness of the system's determinations-and the perception of its legitimacy by affected providers, whose behavior must ultimately be altered if deterrences is to function. Improving confidence may be the most difficult task of all. At times in the malpractice debate partisans on both sides simply refuse to cede any ground: Some doctors want the law to hold that patients assume all risk of adverse medical outcomes short of criminal malfeasance, whereas pro-liability advocates want to hold providers liable for nearly any adverse outcome not specifically explained in advance to patients.

The main issues here are what legal standards of care, causation, and damages are socially appropriate and whether juries and judges in fact apply them correctly, thus creating the proper expectations for the negotiated settlements that dispose of the vast majority of claims. Despite numerous pro-plaintiff doctrinal shifts, the basic "black letter" law remains as a general matter rather favorable to defendants with regard to standards of care. ${ }^{73}$ With regard to causation and damages, the arguments seem persuasive that the law can assess higher compensatory or punitive damages than seems appropriate for deterrence. ${ }^{74}$ Legislatures are now wrestling with substantive tort reforms. Achieving more consensus on basic tort principles would presumably help improve the legitimacy of malpractice deterrence, but it is a

72. See Note, Rethinking Medical Malpractice Law in Light of Medicare Cost-Cutting, 98 Harv. L. Rev. 1004 (1985) (arguing that cost-cutting pressure will increase malpractice liability, so reform is needed). A contrary argument can be made that prospective payment in the long run will lower malpractice standards both by changing the professionally defined customary practice against which the law measures medical behavior and by reducing the expectations of claimants and jurors alike, to the benefit of providers fearful of suit.

73. For example, medical providers are mainly judged by the customary practice of their peers; even following the practice of a "reputable minority" is a defense; and mere "errors of judgment" are excusable. Medical providers, unlike others, are not held to the higher standard of the "reasonable man," that paragon of virtue who like a back seat driver never acts imprudently or takes unnecessary risks. Nor are juries entitled-in law-to make their own assessments of the risks, costs, and benefits of medical activities; they can but choose among the versions presented to them by medical expert witnesses.

74. See supra notes 29,53 and accompanying text. 
difficult goal, given the gulf between many providers and advocates of injured patients.

Those who reject the legal system's accuracy often object that judges and juries too often do not rationally follow the black-letter law but instead make determinations of liability and the extent of damages based on sympathy for injured plaintiffs or other factors. ${ }^{75}$ Like the "frivolous suit" contention, ${ }^{76}$ this one is hard to assess; clearly any pro-plaintiff sympathies operate in less than "knee jerk" fashion, since most claims are closed without payment and most juries find for defendants.

The legitimacy of tort determinations about liability and damages deserves more attention. More systematic information about its outcomes might improve confidence in the system, since almost everyone seems to reach conclusions about its accuracy based on "horror stories" of outrageously overblown verdicts on the one hand, or outrageously bad medical practice on the other. One would have thought that the growing role of provider-owned mutual insurers would have produced more medically oriented claims assessment and settlement practices as well as more information justifying those practices. More independent review of claims files, and more publicity for the findings, might help determine how fairly the system works. ${ }^{77}$ Improvements in dispute resolution, judicial and otherwise, might also heighten the credibility of the system, if clear improvements can be found. ${ }^{78}$

Curiously, little reform effort seems to be directed to understanding or improving the accuracy of judicial decisionmaking or of pretrial settlement. Pretrial screening (with pressures to settle before trial) and arbitration are proffered as alternatives, but without strong documentation of their superiority; and, in any case, both alternatives are strongly influenced by the litigation that remains the source of substantive rules and the ultimate arbitrator of disputes. Perhaps private reforms can develop better arrangements, perhaps not.

75. The popular media's reporting is leaving a growing impression that many court decisionsnot merely for malpractice-have simply taken leave of commonsense reality. E.g., Kilpatrick, Nonsense in the Court, Wash. Post, Dec. 26, 1985, at A19, col. 6. Similarly, the popular picture of the extent of damages available is conditioned by striking headlines. The leading recent example here also comes from outside malpractice. See, e.g., Jury Awards $\$ 10.53$ Billion to Pennzoil in Texaco Case, Wash. Post, Nov. 20, 1985, at Al, col. 2. The award is widely expected to be cut drastically during appeals. (Pennzoil was found wrongfully to have been denied the benefit of its bargain to acquire $43 \%$ of Getty Oil when Texaco bought $100 \%$ for $\$ 10.1$ billion-compared with the jury's finding of $\$ 7.5$ billion in actual damages, $\$ 3$ billion in punitive damages.) Similar, if less flamboyant, stories of apparently foolish or excessive awards abound in malpractice as well; the stories themselves often seem exaggerated. See, e.g., Sorry, America, Your Insurance Has Been Cancelled, supra note 9, at 20-23. To the extent that such mistakes occur in litigation, however, the only possible improvement seems to lie in better judicial oversight-prompted in part by adverse publicity, in part by legislative instructions.

76. See supra text accompanying notes 46-50.

77. Julian, supra note 50 , is one such claims files review.

78. It is discouraging that one study of attitudes about arbitration found that perceptions of its fairness followed interest groupings almost perfectly. Defendants, their lawyers, doctors, and arbitrators thought it was fair. Claimants and their lawyers thought not. Applied Social Research, Inc., Evaluation, State of Michigan Medical Malpractice Arbitration Program, Summary REPORT 15-17 (1983). 
With regard to the performance of courts and juries, it is not clear just what reforms might improve confidence. Some mistakes are inevitable, of course, in any system whose basic standard for assessing liability and damages is "more probable than not"; the question is what proportion of mistakes in each direction is tolerable. To this writer, it appears that legislators who think that awards are often inappropiate (or too high) ought to address judicial administration: how judges determine whether a case is legitimate enough to proceed to trial, what instructions juries receive, how fact finders must explain their decisions, and how judges at trial or on appeal review trial fact finding.

Better disclosure of jury reasoning seems critical. This means more special rather than general verdicts (a necessity in any case where a cap on noneconomic damages must be applied). ${ }^{79}$ It may also mean removing certain technical issues from the jury, such as the application of a discount rate to lost future earnings. Some physicians long nostalgically for the era when medical providers could say "trust me" and most patients would passively accept medical care with little explanation. Society, with informedconsent lawyers often in the vanguard, has moved away from this posture. ${ }^{80}$ Similarly, medical providers seem to have lost trust in the "black box" of legal decisionmaking. Clearer explanations of legal findings, especially with regard to damages, should be helpful. Perhaps damages should be determined separately from liability. In any case, the time seems ripe for more careful consideration of legal process and administration.

2. Increase the Number of Valid Claims in the Deterrent System. Probably the major flaw in the current malpractice system, both for compensation and for deterrence, is that the system has always handled so few cases, even before legislative efforts to cut back claims. It seems bad enough that most negligent damage goes uncompensated, and that the comparative rarity of malpractice claims also complicates premium rate-making, especially for physician coverage. ${ }^{81}$ Worse still for deterrence, the relative absence of "enforcement" through malpractice claims also confounds $q$ quality signals to physicians and other providers of care. The scarcity of claims makes it easier for most providers to believe that the system is random (a belief that is itself a considerable impediment to deterrence) and harder for responsive providers to use claims information for quality control. ${ }^{82}$

79. Cf. Semsch v. Henry Newhall Mayo Memorial Hosp., 171 Cal. App. 3d 162, 169-70, 216 Cal. Rptr. 913,917.18 (1985) (error not to itemize verdict).

80. See, e.g., J. Katz, The Silent World of Doctor and Patient (1984) (arguing that medical tradition militates against patient participation in decisions and that current legal requirements fail to assure it).

81. See supra notes 9,22 and accompanying text.

82. A low rate of enforcement is common but probably less damaging in criminal law. Surely the proportion of speeders evading the highway patrol is even higher, for instance. But for speeders, the (non-insurable) penalty is relatively much higher and, perhaps more importantly, the standards being enforced are clear cut, so that the clarity and strength of deterrent signals are maintained. For negligent medical care, insurance blunts the economic force of deterrence and the legal standards are relatively murky, as indeed are the medical ones on which the law mainly relies to set the standard of care. 
Almost certainly, quality would be better served by a system that detected and dealt with a far higher percentage of negligent injuries than at present. ${ }^{83}$ Handling them all through conventional litigation and settlement would be very expensive. In today's climate, where individual physicians pay most premiums, it seems practical to expand claims frequency intentionally only if one could simultaneously lower the per-case cost in dollars-and, one hopes, also reduce the time and unpleasantness of disputation. Handling more claims more efficiently is the raison d'etre of "no fault" schemes, ${ }^{84}$ but such schemes would surely cost more than today's system in health care dollars, although they might provide larger offsetting gains elsewhere.

No one seems to know how to accomplish the same goals within the tort system. Disputes over medical performance are complicated and the medical testimony required is expensive. It might be that more powerful screening panels, arbitration, mediation, or some as yet unnamed method of dispute resolution could handle malpractice cases more expeditiously and more cheaply without an unacceptable decline in perceived fairness to claimants.

If so, one can imagine a trade-off being made-less access to courts with their full (and expensive) panoply of tort rights for increased access to alternatives. In practice, however, it is difficult to see how such a trade-off could occur. It is relatively easy to curtail access to courts-and quite possibly desirable to move disputes elsewhere-but hard to replace courts with a more attractive deterrent mechanism, since someone must be able and motivated to discover and come forward with valid claims. A public reform that limits the attractiveness of going to court (through restrictions on recoveries or on lawyers' fees, for instance) could simultaneously provide for arbitration, a tribunal modeled on workers compensation boards, or some other process. But it is questionable whether the new process would attract claims for a high enough proportion of negligent injuries to promote deterrence.

Perhaps easier access to a less onerous process would by itself encourage more patients injured by negligence to bring claims. This result could occur if the major reason for low claims frequency today is claimants' dislike of the legal system. ${ }^{85}$ It seems intuitively more plausible, however, that inability to perceive negligence is the main reason. If so, cutting back on access to lawyers and courts would hurt quality incentives because today's major mechanism for finding and investigating claims is to reward lawyers-rather well, many would say-for such policing. ${ }^{86}$ A major agenda item for making such a trade-off attractive from the deterrent point of view is the development of alternative ways to discover negligent injuries and bring them into a deterrent system. Private agreements that create affirmative disclosure or

83. See supra note 22 and accompanying text.

84. See O'Connell, Neo-No-Fault Remedies for Medical Injuries: Coordinated Statutory and Contractual Alternatives, LaW \& CoNTEMP. Probs., Spring 1986, at 125, 127.

85. Cf. Havighurst, supra note 20.

86. The conventional version is that few providers are willing to report adverse incidents, even to their own hospital's risk management program. This observation is based on the author's personal communication from risk managers, June 1985. 
investigatory mechanisms seem to hold more promise in this regard than public rule-making, which probably cannot effectuate such mechanisms. ${ }^{87}$

\section{Improve the "Feedback" Mechanisms that Implement Deterrence. The best} argument that malpractice deterrence does not work is that liability insurance destroys the intended financial incentive of liability payments. Individual professionals or groups that do improve quality must be appropriately rewarded through their insurance rates. Premiums ought to reflect the level of quality achieved, regardless of what scheme applies-fault, part-fault, or no-fault. ${ }^{88}$ Better implementation of risk-reduction measures such as specific advice on risk factors, more peer review, and improved risk management would also aid in deterrence. Partially shifting from individual physician coverage to institutional or group coverage should improve financial incentives and result in risk reductions. The trend toward self-insurance (normally undertaken for other reasons) is good in this regard; perhaps it will spread from hospitals to more groups of individual providers. Nothing can promote conscientious peer review quite like being in the same fiscal boat.

The traditional insurance rating system uses neither insurance experience rating nor specific underwriting or coverage rules effectively to encourage noninstitutional providers to reduce the incidence of malpractice. ${ }^{89}$ Casual observers must find it difficult to take the deterrent effect of insurance rate setting seriously when a rural general practitioner who delivers an occasional baby and the same state's urban obstetricians pay virtually identical rates. Quite notably, experience rating (or its near equivalent, self-insurance) is the rule rather than the exception for hospitals, and it is in hospitals that risk management programs have at least begun to translate malpractice experience into effective preventive measures.

For individual physicians, pure experience rating may be difficult or impossible to achieve because claims frequency is so low and individual risk factors unclear. ${ }^{90}$ Nonetheless, physicians could be given better financial incentives based, at least in part, on their own experience by means of retrospective rating using surcharges or rebates to policyholders, ${ }^{91}$ or by straightforward risk retention through deductibles or coinsurance. ${ }^{92}$ The question of how better to group providers for rating purposes is also important. From a deterrent point of view, insurance groupings should follow natural functional lines of economic and professional interest-just as

87. The Moore bill, for example, cuts back on compensatory obligations only where a provider astutely makes a prompt offer to pay net economic losses to a negligently injured party. Moore \& Hoff, H.R. 3084: A More Rational Compensation System for Medical Malpractice, LaW \& Contemp. Probs., Spring 1986, at 117, 118-19. It is unclear, however, whether this provision would prompt providers to identify faulty conduct and offer payment in more or in fewer cases than now are brought.

88. For a discussion of deterrence under one version of partial no-fault, see Havighurst, Medical Adversity Insurance-Has Its Time Come?, 1985 DukE L.J. 1233, 1249-52, 1263-69.

89. See generally supra notes 56-60 and accompanying text.

90. But see Rolph, supra note 37.

91. See Roddis \& Stewart, supra note 9, at 1302-03.

92. See P. Danzon, supra note 22, at 124-35 (arguing, however, that deductibles may not be economically efficient, given that they may reduce an insurer's incentive to defend claims). 
health insurance sets rates for employment groups by their experience. Such experience rating succeeded initially for financial reasons-it offered lower prices to larger and to lower risk employment groups. It also gave them incentives to control their health care spending, and they have now begun to manage their costs of coverage as well as simply to insure against them. One hopes for similar developments in malpractice insurance.

For physician malpractice coverage, traditional rate-making "groupings" follow no functional lines but are merely large, often statewide, collections of physicians in specialties with historically similar malpractice exposure. ${ }^{93}$ Such synthetic groupings formed only for insurance purposes may adequately spread risk and may be well rated in accordance with their physicians' experience, but such "groups" serve no other business purpose, have no practical coherence, and may well not be stable over time. They thus have almost no ability to respond constructively as a unit to the intended deterrent of higher rates by implementing risk-reducing activities.

Rating based on functional groups would better promote deterrence. For instance, hospitals and their physician staffs could be insured together, as has long been noted. ${ }^{94}$ After all, most malpractice claims originate in hospital care, and joint coverage has considerable advantages from an insurance standpoint, such as higher, more predictable claims frequency, a larger financial base for risk spreading, institutional continuity, economies of scale in marketing and administration, and economies of dispute resolution resulting from including all defendants under one policy.

Current developments make joint hospital-physician coverage even more attractive, especially as a matter of affordability. Hospitals began 1985 with historically high net revenues, despite cost-containment pressures, while physicians' real incomes have been under significant pressure for some time (a reason, one supposes, that almost all the concern over malpractice premiums comes from the latter). ${ }^{95}$ Moreover, the physicians who evidently face the worst malpractice problems today are obstetricians, whose child delivery practice is almost wholly hospital based.96 Finally, hospital prepayment is already fostering hospital-physician joint ventures to promote

93. Id. at 94-95 (on insurance rating practice generally).

94. See, e.g., Roddis \& Stewart, supra note 9, at 1302-03; Steves, A Proposal to Improve the Cost to Benefit Relationships in the Medical Professional Liability Insurance System, 1975 DUkE L.J. 1305.

95. Hospitals Score Record Profits under DRGs, AM. MED. NEwS, Aug. 9, 1985, at 1, col. 1; Holoweiko, Non-surgeon's Earnings: Which Specialties Are Hung Up?, MED. ECON., Feb. 3, 1986, at 206. Moreover, hospital net revenues average some $5 \%$ of gross income, while malpractice protection costs $1 \%$ or less; physicians take home about half of their total income as net earnings, and premiums come to about $4 \%$. A physician facing a $50 \%$ premium hike must cut other expenses by almost $20 \%$ or raise prices by $2 \%$ to avoid a cut in earnings; a hospital need only cut expenses by about $0.5 \%$ or raise prices a similar amount. Further, self-insured hospitals need not worry about being denied coverage in a tight insurance market; they control their own capital.

96. E.g., OBs, Surgeons Fight State Insurance Pinch, AM. MED. NEws, Feb. 14, 1986, at 1, col. 4. Note that obstetricians are not the highest rated physicians; part of their "malpractice" problem may well stem from their lower incomes than higher rated neurosurgeons, for instance. Id. at 26. 
cost control, ${ }^{97}$ a development that could expand to include covering malpractice premiums and working together to control their rising cost.

Joint coverage of all practitioners in a hospital is not an unambiguously positive development, however. It could also increase the economic incentives for everyone with knowledge about an adverse inpatient incident to keep quiet about it. From a strictly financial point of view, suppressing information would be as effective a response as improving quality safeguards.

Not all quality problems occur in hospitals, and other functional groups could also insure or self-insure together, with likely financial as well as deterrent gains. Such groups include HMO's and physician group practices, among others, some of which have already begun to insure themselves jointly. The key is to rate together those with common interest and organization, in order to encourage effective professional "peer review" or other means of effective control. The growth of physician group practices as well as of other groupings of providers made for health insurance purposes are encouraging from this perspective. ${ }^{98}$

Finally, one can hope for improvements in the actual techniques of risk management and other methods of reducing negligence. It does appear that risk management has gained in importance and sophistication since the last "crisis." There may or may not be an important public role in stimulating such efforts or disseminating information about them.

\section{V \\ Malpractice Controls in a Larger Quality Context}

Malpractice is only one of a number of existing and potential social controls over the quality of medical care. Part of the agenda for future reform should be strengthening quality systems generally and matching the appropriate tool to the appropriate task. ${ }^{99}$ On the one hand, the scope of malpractice liability should probably be cut. Lacking better alternatives for patient protection, society may well have come to expect too much from the system. On the other hand, where malpractice rules do apply, they should probably be enforced with more vigor.

It is a mistake to use malpractice liability to govern nearly all diagnostic and therapeutic decisions, as well as provider-patient relations through "informed consent." Malpractice law is too blunt an instrument and applied too uncertainly to address many or most quality problems. Ideally, society wants medical services that are effective, safe in the sense of having known and acceptable inherent risks, and carefully performed. These are quite

97. E.g., Miller, Use of Hospital Data in Medical Staff Discipline, 1 TopICs In Hospital. Law 37 (1985) (emphasizes cost-effectiveness monitoring, not quality per se); see also Warnke, We re Scoring Attendings By $D R G$, Med. ECon., Nov. 12, 1984, at 175 .

98. Many such arrangements are known as "preferred provider organizations." See, e.g., THE New Healthcare Market (P. Boland ed. 1985).

99. Cf. Breyer, Analyzing Regulatory Failure: Mismatching, Less Resirictive Alternatives and Reforms, 92 HaRv. L. REv. 549 (1979) (matching problem in regulatory context). 
different aspects of technical medical quality, but malpractice only deals with the last of them. Moreover, many important aspects of care are nontechnical-accessibility for advice and reassurance, "caring," patient convenience and amenities, and many others. Not all such concerns can be addressed by one quality assurance system, but it sometimes seems that malpractice rules try to cover them all. ${ }^{100}$ This broad scope seems to be one reason that liability makes providers feel so vulnerable, even though a very low proportion of negligent injuries ever appear as claims. Both this broad scope and the law's infrequent application raise conflicting types of quality concerns.

Malpractice rules and lawsuits seem best suited to deal with the carefulness with which the chosen treatment regime is carried out. Indeed, most medical injuries do deal with treatment errors, unforeseen mistakes, and slips of various kinds. ${ }^{101}$ It seems likely that the malpractice system's case-by-case assessment of performance-or something very much like it-needs to be maintained to deal with such problems, which are numerous. It is difficult to imagine informed consumers' voluntarily agreeing to waive rights to adjudicate such cases in some fashion, since such errors by their nature cannot be described in advance. One can hope for, but not confidently predict, that alternative and less expensive ways can be found to resolve such claims, especially ones that are relatively small. For the unusual, very serious, or disabling injuries it is especially hard to imagine a reasonable alternative to a malpractice-like mechanism. Existing compensatory mechanisms leave a considerable gap between the needs of those with major or long-term injuries and the coverage of workplace-based, year-to-year health insurance and shortterm disability coverage which is often lost if a worker must quit because of an injury. ${ }^{102}$ Such unforeseen errors and large injuries are only one variety of quality problems, although they seem to predominate in malpractice insurers' spending.

Several additional points on quality deserve emphasis.

(1) Aside from malpractice claims, other legal and administrative means for promoting quality have been rudimentary at best. Aggrieved patients have traditionally had precious few other avenues than malpractice claims to pursue. The main public control is licensure and state disciplinary proceedings against incompetent physicians. Such measures have not proven

100. Cf. Bovbjerg, supra note 28, at 1385-86 (breadth of malpractice "regulation" of practice).

101. Most medical injuries result from commission (active intervention) rather than omission (for example, diagnostic errors or failure to cure existing problems). Mills, Medical Insurance Feasibility Study, 128 WEST J. MED. 360, 363-64 (1978) (study covered hospital injuries only). Similarly, malpractice claims generally emphasize errors of commission, not omission. NAT'L Ass'N OF INS. Сомм'rs, supra note 22, at 455. See also Danzon's comparative discussion of these other two studies, P. Danzon, supra note 22, at 25-28.

102. Exactly how long such workplace coverages continue to pay for disabling injuries beyond the period of employment is a function of the applicable private contracts and (to a minor extent) of state law on insurance continuation. Medicare covers the permanently disabled (after two years of disability), as does Medicaid, if they "spend down" their income and assets to poverty levels. 
very effective in the past, ${ }^{103}$ and medical professionals have traditionally resisted forms of discipline and even of increased consumer information that are not under tight medical control. A more enlightened and, ultimately, selfinterested posture may be emerging. The American Medical Association, for example, has taken a strong position that strengthened public discipline should accompany malpractice reform. ${ }^{104}$

For whatever proportion of doctors is clearly incompetent, discipline is an important tool. ${ }^{105}$ Nonetheless, licensure and discipline remain even grosser policy implements than malpractice law. Beyond the initial licensure exam, state boards have no regular source of information with which to screen providers-except perhaps reports of malpractice claims, of which they are now sometimes apprised. Further, they cannot very effectively motivate private parties to report problems. Moreover, license revocation is too strong a sanction to be credible except in the very worst cases, and state reviewers are poorly situated to devise or implement better tailored responses to quality problems (for example, reduced hospital staff privileges). Finally, the legal and administrative expenses even of informal administrative hearings probably far exceed those of malpractice claims settlement. The cost of actually withdrawing a license likely goes much higher, since a practitioner wholly denied his livelihood is very apt to sue.

(2) Fortunately, medical ethics and the need to please customers (including fellow professionals, especially those who refer patients) are powerful forces. Most professionals probably have above-average individual dedication to technical competence, although professional groups are no better at disciplining their members in the interest of abstract professionalism than are public boards of discipline. ${ }^{106}$

Consumer pressure and financial incentives are also an important spur to professional competence. The dynamic of quality competition surely works as well for medical care as it does elsewhere in our economy, probably more so, given that health insurance lessens consumers' concerns for the cost of quality enhancement. Society should rely more on consumer pressure for many quality issues. The main role of today's heightened competition is not, or should not be, to force arbitrary cost cuts but rather to promote good value for money spent. A strong consumer role in demanding appropriate quality

103. E.g., Derbyshire, Medical Ethics and Discipline, 228 J. Am. Med. Ass'N 59 (1974); see generally Brook, Brutoco \& Williams, supra note 51, at 1215-17. For more recent developments, see, for example, Feinstein, The Ethics of Professionalism, 312 NEw ENG. J. MED. 801 (1985), and the letters it generated, 313 NEw EnG. J. MED. 390-91 (1985); Murray, Tightening the Patrol for Incompetents, MED. Wortd NEws, Dec. 9, 1985 , at 54.

104. AMA TASk Force, Report 3, supra note 38, at 15-16 (promoting, among other things, crossstate sharing of information on disciplinary actions).

105. Astonishing high numerical estimates exist-for example, that 5 to $15 \%$ of physicians are not fully competent. E.g., Feinstein, [reply to letter writer] 313 NEw EnG. J. MED. 390 (1985). But see Murray, supra note 103, at 55 (questioned on his evidence, Feinstein told reporter "I've just heard it [the estimate] over the years.").

106. See generally supra note 103 and sources cited therein. Discussions of professional selfdiscipline merge with those of state sanctions because professionals rely on referral of cases to state authorities for enforcement. 
could serve to bolster or to replace other mechanisms, including malpractice law.

The key issues for an enhanced consumer role are access to information and the ability systematically to respond to it. The law has little to offer here. The legal doctrine of "informed consent," relying as it does for enforcement on a credible threat of a malpractice action (very rare in practice compared with provider visits), seems irrelevant to consumers' ability to influence almost all medical decisions, ${ }^{107}$ although its existence may help encourage patients to be assertive in their own right. Some reformers may also press for a more structured consumer input, such as membership on state disciplinary boards or hospital boards of trustees, or a required patient ombudsman in medical institutions. ${ }^{108}$

(3) In addition to penalizing subpar providers, providers who have better than average quality need to be rewarded. Only marketplace forces seem equal to this task. Here, it is encouraging that new financing arrangements, like HMO's ${ }^{109}$ and PPO's, ${ }^{110}$ are putting providers at some financial risk for care. If they can improve quality by avoiding even non-negligent bad results, they need not share in paying for extra medical care to help reduce the damage.

(4) The major missing policy tool on the quality front is more active intervention by non-patient "consumers," namely the large health insurers, self-insured employment groups, third-party administrators, and others who pay for and may also arrange for medical care. Strictly with regard to the problem of negligent injuries, such actors are well situated to discover problems by screening unusual patterns of procedures or outcomes of care and then to press subrogation claims. ${ }^{111}$ They could thereby make malpractice claims frequency a better indicator of quality problems and simultaneously reduce the overcompensation problem of double coverage of medical bills by both liability and "collateral" insurers.

Well beyond this malpractice role, payers have the unique ability to gather statistical evidence about the effectiveness of care across the many cases that

107. Cf. J. KATz, supra note 80 (arguing that the doctrine falls far short of entitling patients to needed information and participation). To whatever extent providers' complaints are correct that the doctrine of informed consent allows a patient once injured to claim that he never appropriately agreed to the treatment provided, the doctrine actively impairs the patients' ability to exercise control over their care, because the possibility of the later assertion of a different standard of care will diminish the providers' trust in the patients.

108. Cf. Donabedian, supra note 33, at 22-24.

109. See supra note 29.

110. See supra note 98 .

111. The federal Health Care Financing Administration recently released a compilation of data on hospitals' patient mortality by category of patient or "diagnosis-related group" (DRG). See Brinkley, U.S. Releasing Lists of Hospitals with Abnormal Mortality Rates, N.Y. Times, Mar. 12, 1986, at A1, col. 3. This action drew severe criticism from hospitals and praise from consumer groups; the list is controversial because it was meant only as a screening device, not as a quality finding. A decade ago, consumers lost a lawsuit seeking disclosure of provider data from federally-sponsored but private professional standards review organizations. Public Citizen Health Research Group v. Dep't of HEW, 668 F.2d 537, 543 (D.C. Cir. 1981). 
involve their insureds. They can thus deal with problems that are simply impossible to detect or assess on a case-by-case basis, whether in court or through isolated clinical judgment. ${ }^{112}$ To date, payers' management efforts have concentrated on cutting costs; they should be encouraged to begin to try to improve quality as well. ${ }^{113}$ This suggestion implies a greater purchaser role in setting standards, which for the medical professions is a double-edged sword: More active consumers may help redefine malpractice expectations, but their incursions into traditional professional prerogatives will not please medical professionals. Similarly, providers who seek to negotiate private agreements to supersede or supplement malpractice law may find the negotiations rather demanding. Well-informed employment groups with considerable bargaining power are apt to be the first to agree to negotiations, if not the only ones allowed by courts to make agreements changing tort law. ${ }^{114}$

(5) Insurers and other payers are becoming insistent that medical providers provide care more efficiently, or just more cheaply, than under previous patterns of open-ended coverage and little constrained payment levels. Providers often fear malpractice suits if a bad result occurs after they have omitted any element of desirable-or potentially desirable-care that insurers or patients are no longer reimbursing. Indeed, both public and private payers are retreating from the previous ideal of maximum quality at any price.

It is unclear to what extent the law will recognize new approaches to establishing acceptable levels of quality, including risks of injury now handled by malpractice law. Relying less on malpractice rulings and more on other quality measures calls for willingness to make some adjustments. This will require broad acceptance of advance contracts about liability (probably the hardest to "sell"), more reliance on truly informed consent (easier to accomplish in court, harder in hospitals), or better explanations by defendants about why alleged deficiencies were in fact economically and socially desirable in cases of particular injuries (also difficult). In short, if medical professionals want to be held less responsible in court for quality problems, they need to make their practices more directly accountable to patients, payers, and other forms of lay judgment.

112. Many quality issues are essentially statistical - how much better is one technique than another, for instance-not all or nothing, as under malpractice, which asks whether a technique is professionally acceptable or not under the particular circumstances. See, e.g., Bovbjerg, supra note 28, at 1390-1407 (HMO's that use noncustomary methods may be penalized in each case of bad outcome despite overall statistically similar or superior results); see also McClure, Buying Right: The Consequences of Glut, Bus. \& Health, Sept. 1983, at 43 (medical quality is statistical, "like a batting average"; one or two medical episodes or baseball games do not tell the full story). It is unclear to what extent courts and judges will allow the use of statistical evidence as opposed to direct testimony on a caseby-case basis when a doctor's hospital privileges are at stake, for instance. See Miller, supra note 97.

113. Cf. Shaughnessy \& Kurowski, Quality Assurance Through Reimbursement, 17 Health Serv. Res. 157 (1982) (potential advantages of integrating payment and quality assurance); see also Bovbjerg \& Havighurst, Medical Malpractice: An Update for Noncombattants, Bus. \& Health, Sept. 1985, at 38.

114. See Fine \& Sunshine, supra note 14, at 221; Ginsburg, Kahn, Thornhill \& Gambardella, Contractual Revisions to Medical Malpractice Liability, LAw \& ConTEMP. Probs., Spring 1986, at 253, 256. 
It is tempting to call for direct trade-offs among alternative quality protections to be made in the course of the malpractice reform debates now under way. To an extent, this seems to be occurring, as calls are heard for increased state discipline as a quid pro quo for malpractice "relief" for providers. Only in such limited ways do political trade-offs seem feasible. Most of the desirable quality changes call for long-term efforts by many affected parties, not a straightforward, one-time legislative solution. States could constructively address some quality and malpractice issues through their own health insurance plans that cover state employees. States could also allow and encourage private plans to do so, including adopting alternative malpractice regimes in appropriate cases.

"The" malpractice problem is not solely a problem of negligence and insuring against it, but rather is part of the larger issue of deciding on and enforcing desired levels of medical quality. For the second time in a decade, public attention has focused on medical liability issues, largely from an insurance perspective. After the last "crisis" was "solved," or at least outlasted, attention waned. One hopes that a constructive byproduct of current concern will be greater and longer-lasting attention to the many aspects of medical quality by both public and private actors. 